\title{
The syntaxonomic and species diversity of the class Festuco-Brometea Br.-Bl. ex Klika \& Hadač 1944 in the area of Prečko Polje
}

\author{
Sintaksonomska raznolikost i raznolikost između vrsta razreda \\ Festuco-Brometea Br.-Bl. ex Klika \& Hadač 1944 u području \\ Prečkog Polja
}

\author{
Sabina Trakić1,
}

I University of Sarajevo, Faculty of Science, Department of Biology, Zmaja od Bosne 33-35, Sarajevo, Bosnia and Herzegovina

\begin{abstract}
The ecosystems of the class Festuco-Brometea in Bosnia and Herzegovina play an important role in the overall biological diversity. They are distinguished by a large number of vegetation units, as well as by significant number of rare, endemic or relict plant species. The study area, Prečko polje, covers 1.27 at $1100 \mathrm{~m}$ a.s.l., and takes place in the heart of mountain complex Treskavica-Visočica-Bjelašnica. We analised thermophylous meadows of Prečko polje after method of phytocoenological relevé. The class Festuco-Brometea in study area is being differentiated into the alliances Xerobromion erecti (with suballiance Fumano-Scabiosenion leucophyllae) and Mesobromion erecti (with suballiance Eu-Mesobromenion). In general, thermophylous meadows are characterized by high degree of species diversity. Moreover, within thermophylous meadows of Prečko polje we have identified nine species which are considered to have certain conservation status, according to the national and/or international legislation. Our study has shown that investigated area should be considered as potential Natura 2000 site for it is inhabited by a significant number of rare and/or endangered orchid species.
\end{abstract}

Key words: thermophylous meadows, diversity, orchid site, protection measures.

\section{INTRODUCTION - Uvod}

The results of numerous ecological studies have shown that vegetation of the Balkan peninsula expresses high heterogeneity in respect of both its floristic composition and syntaxonomy. This is especially the case for xerophyllous vegetation of the class Festuco-Brometea (Redžić, 1999). There is investigation continuity regar- ding this vegetation type in Bosnia and Herzegovina (Lakušić, 1975; Lakušić et al., 1984; Redžić, 1984; Redžić et al., 1984; Redžić, 1997, 1999; Riter-Studnička, 1956, 1974). In the area of Balkan, thermophylous meadows have secondary character, for they were formed by degradation of climax communities, such as Carpinion orientalis Blečić \& Lakušić 1966, Ostryo-Carpinion orientalis Horvat 1954 emend. 1958, Quercion farnetto Horvat

Corresponding author: Sabina Trakić, Faculty of Science University of Sarajevo Department of Biology; Zmaja od Bosne 33-35, 7 I000 Sarajevo, Bosnia and Herzegovina; e-mail address: strakic@email.com 
1954 in the supramediterranea area, and Seslerio-Ostryon Lakušić, Pavlović \& Redžić 1982, Quercion petraeae-cerris (Lakušić, 1976) Lakušić \& B. Jovanović 1980, Quercion pubescentis-petraeae Br.-BI. I93I, Fagion moesiacae Blečić \& Lakušić 1970 and Fagion illyricum Horvat (1938) 1950 in the supramediterranean-mountain and partially mountain belt (Redžić, 1999). The phytocoenoses of the class Festuco-Brometea develop on limestone, dolomite, dolomitized limestone, silicate, diabase or serpentine, whereby the soil can be calcomelanosol, eroded calcomelanosol, rendsine or deeper type of soil which is physiologically dry. The $\mathrm{pH}$ value of soil varies between 6,5 and 7,5. The phytocoenoses of the class Festuco-Brometea develop under warm and dry habitat conditions, frequently on southern, southeastern or southwestern slopes. Mean annual temperature varies between $+12^{\circ} \mathrm{C}$ and $+5^{\circ} \mathrm{C}$. Absolute minimum is $-20^{\circ} \mathrm{C}$, whereas absolute maximum reaches $+45^{\circ} \mathrm{C}$. Mean annual air humidity varies between 60 and $40 \%$. The phytocoenoses encompass species which are typical heliophytes (Barudanović et al., 20I5). From the ecological point of view, they are being differentiated into alliances: Mesobromion erecti and Xerobromion erecti (Redžić, 1999). Due to its origin and distribution range of characteristic species, thermophylous meadows play an important role when it comes to maintenance of endemic genpool on global scale (Barudanović et al., 2015). Comparative analises have shown that class Festuco-Brometea on the Balkan is characterized by high species and syntaxonomic diversity with 1000 recorded taxa, and more than 100 described phytocoenoses. Average number of species per association varies between 90 and 230, which places them among the ecosystems with the highest species diversity level (Redžić, 1999).

\section{Investigated Area - Područje istraživanja}

Geographic position. The Prečko polje is situated at $1100 \mathrm{~m}$ a.s.l., in the heart of mountain complex Treskavica-Bjelašnica-Visočica, covering the area of $\mathrm{I} .27$ square kilometers. It is determined by coordinates $\mathrm{N}$ $43^{\circ} 42^{\prime} 7.34^{\prime \prime}$ E $18^{\circ} 19^{\prime} 57.43^{\prime \prime}$ (Fig. I).

Geology. The Prečko polje is built of thick deposits from the Triassic period. The early Triassic deposits are arenites and conglomerates of fine granulation, whereas the late Triassic is represented by limestone, dolomite and sedimentary rocks of breccia type. The most significant geological feature is presence of reddish silicate from the early Perm, which is covered by limestone layers with fossilized remains of brachiopods, Echinodermata and red algae (Hrvatović, 2006).
Pedology. In the area of Prečko polje occur automorphous soils of the humus-accumulative class, whose pedological profile is A-C. Soil types are calcomelanosol and rendsine depending on the type of parental rocks.

Climate. The investigated area is characterized by mountainous climate with harsh winter conditions and short, warm summer. Mean annual precipitation amounts $1202,4 \mathrm{~mm}$, and mean annual temperature is $+7,3^{\circ} \mathrm{C}$. The absolute maximum is $+35^{\circ} \mathrm{C}$, whereby minimum is $-30^{\circ} \mathrm{C}$ (Strategija održivog razvoja Općine Trnovo za period 20I2-2 106. Općina Trnovo, 20I2).

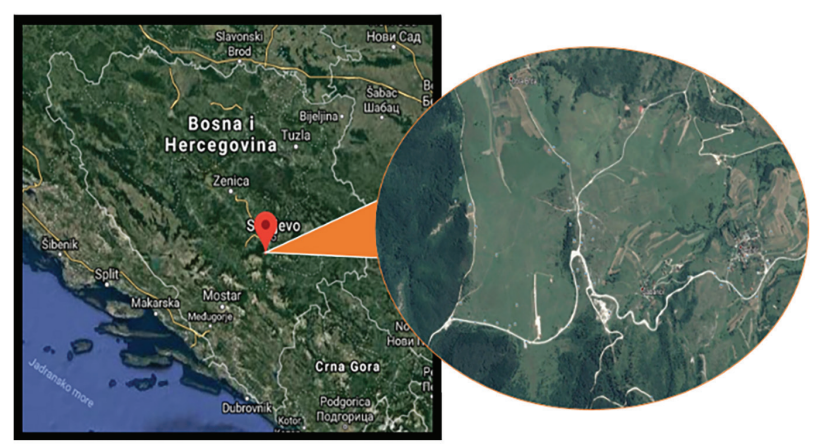

Figure I - Position of Prečko polje in Bosnia and Herzegovina (Google Earth, 2018)

Slika I - Položaj Prečkog polja u

Bosni i Hercegovini (Google Earth, 2018)

\section{MATERIAL AND METHODS - Materijal i metode}

Investigation in the field was conducted according to the method of SIGMA (Braun-Blanquet, 1964), whereby plant material was collected for further identification purposes. For the identification of taxa we used Domac (1989) and Javorka and Csapody (1979). The nomenclature is given after Tutin et al. (1964-1980). In order to evaluate microclimate conditions for the investigated phytocoenoses, we analised floral elements and life forms according to Oberdorfer (1979). The syntaxonomy is given after Lakušić et al. (1978).

\section{RESULTS AND DISCUSSION - Rezultati i diskusija}

The analysis of species and syntaxonomic diversity of thermophylous meadows in Prečko polje was based on twelve reléves that were made in spring, summer and autumn aspects, in the year 2017. According to our results, thermophylous meadows in Prečko polje differentiate as follows: 
- Class: Festuco-Brometea Br.-BI. Ex Klika \& Hadač 1944

- Order: Brometalia erecti (W. Koch 1926) Br.-BI. 1936

- Alliance: Xerobromion erecti (Br.-BI. \& Moor 1938) Moravec in Holub et al. 1967

- Sub-alliance: Fumano-Scabiosenion leucophyllae Redžić 1991

- Association: Potentillo-Scabiosetum leucophyllae Redžić 1991

- Association: Scabiosetum leucophyllae Abadžić 1973

- Association: Globulario-Scabiosetum leucophyllae Redžić, Lakušić et al. 1984

- Alliance:Mesobromion erecti (Br.-Bl. et Moor 1938) Oberd. 1957

- Sub-alliance: Eu-Mesobromenion Oberd. 1957 (= Cirsio acauli-Bromenion Redžić 1991)

- Association:Bromo-Brachypodietum pinnate Petkovsek 1977

- Association: Bromo-Plantaginetum mediae Horvat (193I) 1949
The phytocoenoses of the alliance Xerobromion erecti occur on northern slopes of Prečko polje. The inclination of localities, with southern aspect, spans from 5 to $20^{\circ}$. The parental rocks are limestone, and soil is shallow, rocky calcomelanosol. The vegetation coverage varies between 90 and $95 \%$. In the floristic composition were identified 104 species, of which the most frequent were: Scabiosa leucophylla Borbás, Teucrium chamaedrys L., Cirsium acaulon (L.) Scop., Plantago media L., Anthyllis vulneraria L., Veronica jacquinii Baumg., Euphorbia cyparissias L., Potentilla tommasiniana F. W. Schultz, Prunella laciniata (L.) L., Leontodon crispus Vill., Juniperus communis $L$. and Lotus corniculatus $L$.

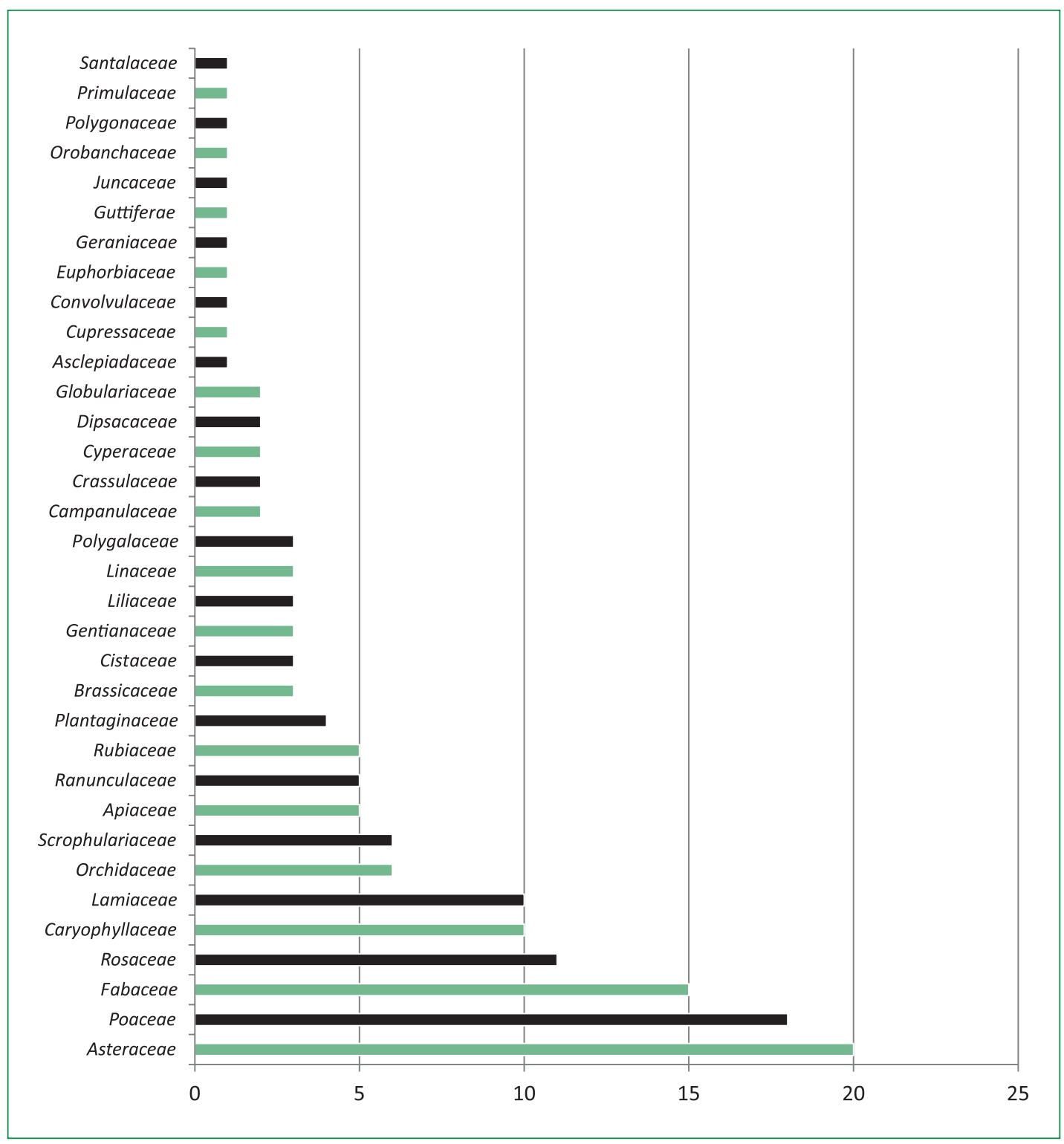

Graph I - Proportion of plant families in the composition of thermophylous meadows in Prečko polje

Grafikon I - Zastupljenost porodica biljaka u kompziciji termofilnih livada na Prečkom polju 
The phytocoenoses of the alliance Mesobromion erecti occur in southern slopes of Prečko polje. The inclination of localities reaches up to $30^{\circ}$, whereas the aspect is northeast or west. Inspite of unfavorable aspect, thermophylous meadows occur here due to the great inclination and partially dolomite ground. In the floristic composition were identified $12 \mid$ species, of which the most frequent were: Scabiosa leucophylla Borbás, Teucrium chamaedrys L., Filipendula hexapetala Gilib., Thymus serpyllum L., Cirsium acaulon (L.) Scop., Plantago media L., Centaurea pannonica (Heuff.) Simonk., Galium verum L., Bromus erectus Huds. Inula britannica L. and Trifolium montanum L.. Differential species in relation to the alliance Xerobromion erecti are: Galium verum L., Bromus erectus Huds., Inula britannica L., Trifolium montanum L., Festuca heterophylla Lam., Agrimonia eupatoria L, Brachypodium pinnatum (L.) P. Beauv. and Ononis spinosa L.

In total, thermophyllous meadows of Prečko polje encompass 155 species belonging to 35 plant families (Graph I).Average number of species per association is 42. Since thermophyllous meadows are distinguished by much higher level of species diversity (Redžić, 1999), the obtained result in Prečko polje reflects harsh environmental conditions caused by mountainous climate in the investigated area. The highest proportion of species belongs to the families Asteraceae (20), Poaceae (I8), Fabaceae (I5), Rosaceae (I2), Caryophyllaceae (I0), Lamiaceae $(10)$. With five or six species represented were families: Orchidaceae, Scrophulariaceae, Apiaceae, Ranunculaceae and Rubiaceae. Remaining families have much lower proportion in the floristic composition of thermophylous meadows of Prečko polje. The most frequent species were: Scabiosa leucophylla Borbás, Teucrium chamaedrys L., Cirsium acaulon (L.) Scop., Plantago media L., Anthyllis vulneraria L., Veronica jacquinii Baumg., Euphorbia cyparissias L., Filipendula hexapetala Gilib., Genista sagittalis L., Potentilla tommasiniana F. W. Schultz, Centaurea pannonica (Heuff.) Simonk., Leontodon crispus Vill. and Prunella laciniata L..

By analyzing the spectrum of life forms according to Raunkier (Graph 2), hemicryptophytes $(H)$ prevail in the flora of thermophylous meadows in Prečko Polje, indicating climate conditions of wider macro-region. Relatively high proportion of chamaephytes $(\mathrm{Ch})$ is caused by mountain microclimate. On the other hand, geophytes $(G)$ and therophytes (T) represent life forms that are characteristic for steppe and desert areas and indicate thermophylous and xerophylous habitat conditions.

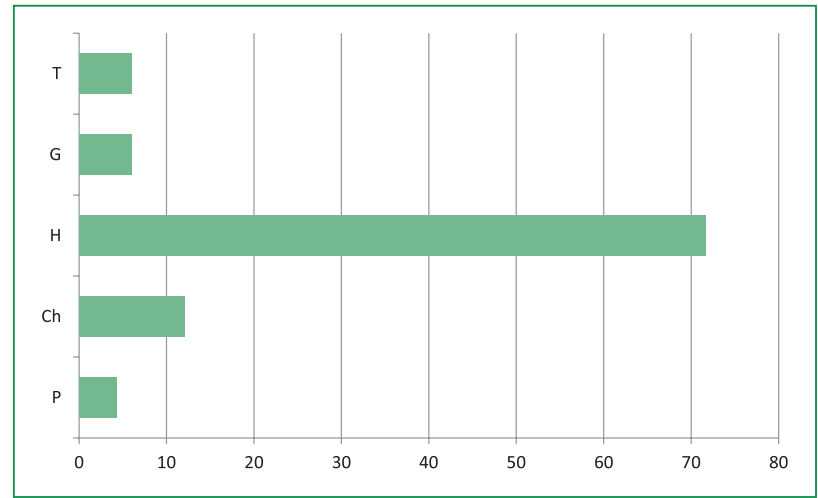

Graph 2 - Spectrum of life forms of thermophylous meadows in Prečko polje

Grafikon 2 - Spektar živućih formi termofilnih livada u Prečkom polju

According to the spectrum of floral elements (Graph 3), thermophylous species with a center of distribution in the sub-Mediterranean belt play a dominant role in the floristic composition of thermophylous meadows in Prečko polje (21\%).A relatively high proportion of species of suboceanic and sub-atlantic floral elements $(26 \%)$ indicates the perhumide character of the climate. Despite the large amount of rainfall, xerophilic conditions in Prečko polje occur due to the water-permeable character of the parental rocks (limestone and dolomite). Species of which ecological optimum is in the area of northeast Europe (noeuras) and the species of prealpine (pralp) and alpine (alp) floral elements also have high proportion in the spectrum (20\%). Such a significant proportion of frigoriphic species is the function of altitude, i.e. the mountain climate in the area of Prečko polje. From the aspect of natural values for the investigated area, it is important to highlight the species of Balkan floral element (3\%).

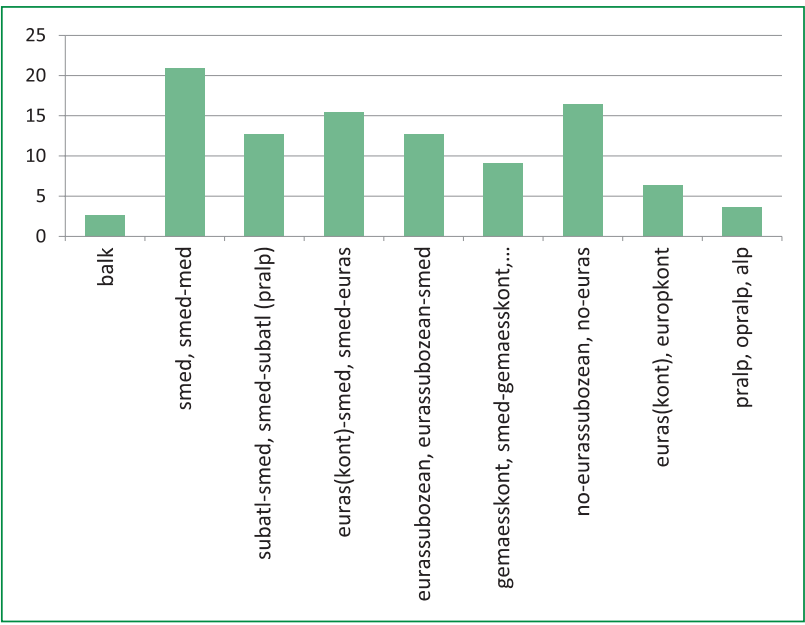

Graph 3 - Spectrum of floral elements of thermophylous meadows in Prečko polje

Grafikon 3 - Spektar flornih elemenata termofilnih livada u Prečkom polju 
Considering the fact that we have found six species from the familiy Orchidaceae, there is a possibility of designating the area as a priority in terms of protection. According to the "Management of Natura $2000 \mathrm{Habi}$ tats" (2008), habitat is considered as a protection priority $\left(6210^{*}\right)$ if it represents a significant orchid site. Significant habitats of orchids are determined on the basis of one or more of the following criteria:

(a) the habitat covers a rich suite of orchid species;

(b) habitat covers an important population of at least one orchid species which is considered not very common in the national territory;

(c) one or more orchid species that are considered rare, very rare or exceptional on the national territory are present on the habitat.

The orchids recorded in the area of Prečko polje are Orchis tridentata Scop., Orchis morio L., Orchis ustulata L., Anacamptis pyramidalis (L.) Rich., Listera ovata (L.) R. Br. and Cephalanthera ensifolia Rich., of which three have defined conservation status according to national and/ or international legislation. In addition, the widespread ecological significance of the class Festuco-Brometea is reflected through the presence of predatory bird populations for which these meadows represent hunting grounds in the mating period. There are also many migratory birds nesting on thermophylous meadows. In addition, thermophylous meadows represent a significant habitat for butterfly fauna.

\section{CONCLUSIONS - Zaključci}

Numerous studies have highlighted the complexity of the structure and dynamics of vegetation, and especially the problems in syntaxonomy and ecological differentiation of xerophilic and rocky meadows in the Balkans. Floristic and ecological analyzes show that the communities of the class Festuco-Brometea in Balkans are significantly different from the ones in Western, Central and Eastern Europe through the presence of Balkan, Illyrian and Southeast European floral elements. This emphasizes the need for additional revision of the status of the class Festuco-Brometea and its phytocoenologycal differentiation as well as their connection with the most relative rocky meadows (Redžić, 1999). According to the clear differentiation of alliances Xerobromion and Mesobromion in the area of Prečko polje, the result of the floristic-vegetation research represents a contribution in context of the observation for all ecological specificities of lower syntaxonomic categories of the class Festuco-Brometea. In order to raise ecological awareness of the specificity and significance of the ecosystems of Prečko polje and to create the prerequisites for the establishment of measures for the protection of local populations of orchids, and taking into account the principles of ecosystem approach, it is necessary to investigate the structure and dynamics of all vegetation types in the investigated area.

\section{REFERENCES - Literatura}

Barudanović S., Macanović A., Topalić-Trivunović Lj. \& Cero M. (20I5): Ekosistemi Bosne i Hercegovine u funkciji održivog razvoja, Prirodno-matematički fakultet, Sarajevo

Braun-Blanquet J., (1964): Pflanzensoziologie. Springer Verlag, Wien - New York.

Domac R. (1984): Mala flora Hrvatske i susjednih područja, Školska knjiga, Zagreb

Google maps (2018). Retrieved from https://www.google.com/maps

Hayek A. (1927-1933): Prodromus Florae Peninsulae Balcanicae, Berlin

Hrvatović H. (2006): Geological guidebook through Bosnia and Herzegovina, Geological Survey of Federation Bosnia and Herzegovina, Sarajevo

Jávorka S. \& Csapody V. (1979): Ikonographie der Flora des südöstlichen Mitteleuropa, Akadémiai Kiadó, Budapest

Lakušić R., (1975): Prirodni sistem geobiocenoza na planinama Dinaridima. God. Biol. inst. Univ. u Sarajevu 28:|75-19|.

Lakušić R., Pavlović D., Abadžić S. and Grgić P., (1978): Prodromus biljnih zajednica Bosne i Hercegovine. God. Biol. inst. Univ. u Sarajevu 30: 5-87.

Lakušić R., Redžić S. and Muratspahić D., (1984): Zakonitosti singeneze vegetacije na vertikalnom profilu Orjena. Bilten Drust. Ecol. B\&H, b, 2: 287- 297.

Management of Natura 2000 habitats (2008). Retrieved from http://ec.europa.eu

Oberdorfer E. (1979): Pflanzensoziologische Exkursionsflora, Verlag Eugen Ulmer, Stuttgart

Općina Trnovo (20I2): Strategija održivog razvoja Općine Trnovo za period 2012-2106. Retrieved from http://www.trnovo.ba 
Redžić S., (1984): The syndinamic relationship some non-forest phytocoenoses on vertical profile Sarajevo - Bukovik Mt. Bilten Drust. Ecol. B\&H, b, 293-296

Redžić S., (1997): Brometalia erecti (W.Koch 1926) Br.BI. 1936 of the Central \& Western Balkans. First Balkan Botanical Congress. Abstract Book.

Redžić S., Lakušić R., Muratspahić D., Bjelčić Z. and Omerović S., (1984): The structure and dynamics of phytocoenoses in the ecosystems of Cincar andVitorog Mts. God. Biol. inst. Univ. Sarajevo, 37: I23- 177.

Redžić S. (1999): The syntaxonomical differentiation of the Festuco-Brometea Br.-BI. \& R.Tx. 1943 ex Klika \&
Hadač 1944 in the Balkans, Annali di Botanica, Vol.LVII

Riter-Studnička H., (1956): Flora i vegetacija na dolomitima Bosne i Hercegovine. God. Biol. inst. u Sarajevu 9: 73-122.

Riter-Studnička H., (1974): Neue Pflanzengesellschaften aus Karstfeldern Bosniens und der Hercegovina. Bot. Jahrb. Syst. 92 (I): 108-154.

Tutin T.G. , Heywood V.H., Burges N. A. , Moore D. M., Valentine D. H.Walters S. and Weeb D. A. (eds.) (1964 - 1980): Flora Europea. Vol. I -V. Cambridge University Press, Cambridge, London, New York, New Rochelle, Melbourne, Sydney.

\section{SAŽETAK}

Ekosistemi razreda Festuco-Brometea u Bosni i Hercegovini igraju važnu ulogu u ukupnoj biološkoj raznolikosti. Odlikuje ih veliki broj vegetacijskih jedinica, kao i značajan broj rijetkih, endemskih ili reliktnih biljnih vrsta. Područje proučavanja, Prečko polje, prostire se na $1,27 \mathrm{~km}]$ ^ 2 na 1100 m.š., a nalazi se u srcu planinskog kompleksa Treskavica-Visočica-Bjelašnica. Analizirali smo termofilne livade Prečkog polja metodom fitocenološkog relevea. Klasa Festuco-Brometea u istraživanom području se diferencira na saveze Xerobromion erecti (sa podsavezom Fumano-Scabiosenion leucophyllae) i Mesobromion erecti (sa podsavezom Eu-Mesobromenion). Generalno, termofilne livade karakteriše visok stepen raznolikosti vrsta. Štaviše, unutar termofilnih livada Prečkog polja identificirali smo devet vrsta za koje se smatra da imaju određeni status zaštite, prema nacionalnom i / ili međunarodnom zakonodavstvu. Naše istraživanje pokazalo je da istraženo područje treba smatrati potencijalnim Natura 2000 nalazištem jer u njemu živi značajan broj rijetkih i / ili ugroženih vrsta orhideja. 